of knowledge and of results of research and practical experience by organising conferences and publishing annual reports reviewing the development of soil mechanics which each country has made during the year. The statutes of the Society provide for a number of national organisations, and the British Section of the Society has now been formed and is administered by the British National Committee. Membership is open to all interested in soil mechanics and its applications. There is a registration fee of $£ 2$, and the annual subscription is $10 s$. Full particulars can be obtained from the Secretary to the British National Committee at the Institution of Civil Engineers, Great George Street, London, S.W.1.

\section{Science Masters' Association (Scottish Branch) :} Meeting in,St. Andrews

DURING April 12-14 the annual general meeting of the Scottish Branch of the Science Masters' Association will be held in St. Leonard's School, St. Andrews. Sir James Colquhoun Irvine, principal and vicechancellor of the University of St. Andrews, will preside at the meeting. The programme for the three days is very full and consists mainly of scientific lectures, exhibitions, and visits and excursions. This branch of the Association was formed in January 1947 , and the first annual general meeting was held at the University of Glasgow in April 1948. The organising secretary for the St. Andrews meeting is Mr. F. G. Daldy, of Trinity College, Glenalmond, and $\mathrm{Mr}$. Daldy and Mr. J. Wallace, of Melville College, Edin burgh, are joint secretaries of the Scottish Branch.

\section{Publication of Scientific Papers}

AT the Scientife Information Conference held last year, the Royal Society was invited to approach printing organisations with the view of setting up permanent relations for maintaining understanding and co-operation with scientific publishing bodies. It is proposed to arrange a meeting shortly to discuss the current position with regard to scientific publishing and printing. The Royal Society will be glad to receive any statement of difficulties and suggestions for discussion. Comments should be addressed to the Assistant Secretary, Royal Society, Burlington House, Picquplily, London, W.1.

\section{Publication Difficulties of American Physics} Journals

IN the February issue of Physics Today, it is mentioned that wit in a few months many of the American physi oy,ournals would appear with reduced margins andy th less space between the lines. By this mpar s, without altering the page size, it is hoped to add Wwenty per cent to the content of each page, and thus, by saving in press work and paper, to meet the cost of publication despite the fact that costs and the volume of contributed material are rising faster than income. Another suggestion, which may yet have to be put into practice, is to use a more compact type-face. For the Journal of Chemical Physics, figures are quoted which show that there has been a steady rise in the number of printed pages, from about 600 in 1944 to 1,250 in 1948, with, in addition, a steady rise in the cost of production per page. It is estimated that 2,000 pages will be required in 1949. This is not confined to the Journal of Chemical Physics, but is typical of the other journals published by the American Institute of Physics; and the executive committee of the Institute has been contemplating some form of restriction on publication. Neither increased advertising income nor increases in subscriptions are considered to be a solution, and readers of the journals are asked to give their views and suggestions as to methods to meet the present serious situation.

\section{Announcements}

THe Council of the Linnean Society of London has awarded the Linnean Medal for the year 1949 to Prof. D. M. 8. Watson, Jodrell professor of zoology and comparative anatomy at University College, London. Linnean Medals have also been awarded to Dr W. T. Calman, lately keeper of zoology in the Tritish Museum (Natural History), and Prof. F. E. Weiss, emeritus professor of botany in the University of Manchester, in respect of the war years during which no awards were made.

THE first mexting of the United Kingdom National Commission for Unesco is to be held at Church House, Westminster, on April 11 at 10.15 a.m. The National Commission consists of about 250 members represent. ing important organisations in the fields of education, science and culture. Mr. George Tomlinson, Minister of Education, will be in the chair, and among the speakers will be Dr. Torres Bodet, director-general of Unesco. Morning and afternoon sessions will deal with the work of Unesco.

A MEETy of the European Hæmatological Society will bo held in Montreux (Switzerland) during Septomber 15-17, 1949, to discuss hæmolytic anamias, and variations of blood proteins in blood dyscrasias. Further information can be obtained from Dr. A. Piney, 152 Harley Street, London, W.1.

A GENERAL constituent assembly for the foundation of the Permanent Council for the Co-ordination of International Congresses of Medical Sciences will be held in the Palais des Académies, rue de la Loi, Brussels, during April 4-9. This conference is sponsored jointly by the United Nations Educational, Scientific and Cultural Organisation and the World Health Organisation at 141 rue Belliard, Brussels.

THE Central Council for Health Education will hold its 1949 pesidential Summer School in Health Education the School of Domestic Economy, Eastboune, during July 28-August 11, under the direction of Dr. Robert Sutherland. The school will be of interest to all concerned with health education and should be of special value to medical men, teachers, public health nurses, industrial nurses, industrial welfare workers, social workers, etc. Further information can be obtained from the Medical Adviser and Secretary, Central Council for Health Education, Tavistock House, Tavistock Square, London, W.C.1.

THE Develppment Commissioners, in association with the Ministry of Agriculture and Fisheries and the Scothrsh Home Department, offer postgraduate trainipg grants of $£ 220-300$ per year, tenable from October 1,1949 , for training men and women in the investigation of problems in marine and freshwater science. The grants (about five in number) are open to honours graduates in science of a British university, and are tenable for one year with renewal up to a maximum of three years. Forms of application (to be returned by May 1) and full details may be obtained from the Secretary, Development Commission, $6 a$ Dean's Yard, Westminster, London, S.W.l. 